\title{
PERSEPSI PETANI TERHADAP ASURANSI USAHA TANI PADI (AUTP) DI KECAMATAN PALETEANG, KABUPATEN PINRANG, PROVINSI SULAWESI SELATAN
}

\author{
Perception of Farmers On Rice Farming Insurance Program (AUTP) In Paleteang \\ District, Pinrang Regency.
}

\author{
Muhammad Algazali*, Muh. Hatta Jamil, Nurdin Lanuhu. \\ Program Studi Agribisnis, Departemen Sosial Ekonomi Pertanian, \\ Fakultas Pertanian, Universitas Hasanuddin, Makassar \\ *Kontak penulis: algazali2208@gmail.com
}

\begin{abstract}
Abstrak
Asuransi pertanian penting dilakukan karena ketidakpastian yang menyerang hampir seluruh petani di Indonesia sehingga potensi untuk terjadinya gagal panen menjadi sangat tinggi. Penelitian ini bertujuan untuk: 1) Menganalisis mekanisme Asuransi Usaha Tani Padi (AUTP) di Kecamatan Paleteang, Kabupaten Pinrang, 2) Menganalisis Persepsi petani Terhadap Asuransi Usaha Tani Padi (AUTP) di Kecamatan Paleteang, Kabupaten Pinrang, 3) Menganalisis faktor-faktor yang berhubungan dengan persepsi petani Terhadap Asuransi Usaha Tani Padi (AUTP) di Kecamatan Paleteang, Kabupaten Pinrang. Penentuan Sampel dilakukan dengan mengambil sampel sebanyak 15\% dari populasi berjumlah 165 orang, sehingga sampel dalam penelitian ini berjumlah 30 responden. Analisis data yang digunakan untuk menjawab tujuan pertama, kedua dan ketiga adalah analisis deskriptif, untuk menganalisis persepsi petani digunakan Skala Likert dengan kriteria untuk setiap tanggapan masing-masing kategori adalah $3=$ sangat setuju, 2 = setuju, $1=$ kurang setuju, dan untuk mengetahui tentang faktor-faktor yang berhubungan dengan persepsi petani terhadap AUTP dianalisis dengan menggunakan uji korelasi Rank Spearman. Hasil penelitian menunjukkan: 1) Mekanisme Pelaksanaan program AUTP di Kecamatan Paleteang telah berjalan baik, namun sosialisasi mengenai program kurang menyeluruh ke semua petani, 2) Persepsi petani terhadap AUTP dibagi atas 3 aspek yaitu persepsi petani terhadap organisasi pelaksanaan AUTP berada pada kategori setuju, persepsi terhadap pelaksanaan AUTP berada pada kategori setuju, dan persepsi petani terhadap monitoring, evaluasi, dan pelaporan AUTP berada pada ketogori setuju, 3) Terdapat hubungan antara faktor - faktor yang mempengaruhi persepsi (umur, pendidikan, luas lahan, premi, dan pengetahuan) dengan persepsi petani terhadap AUTP.
\end{abstract}

Kata Kunci: Persepsi, program asuransi usaha tani padi

\begin{abstract}
Agricultural insurance is important because of the uncertainty that attacks almost all farmers in Indonesia so the potential for harvest failure is very high. This study aims to: 1) Analyze the mechanism of Rice Farm Business Insurance (AUTP) in Paleteang District, Pinrang Regency, 2) Analyze farmers' perceptions of Rice Farming Insurance Program (AUTP) in Paleteang District, Pinrang Regency, 3) Analyzing factors related to farmers' perceptions of Rice Farm Insurance Program (AUTP) in Paleteang District, Pinrang Regency. Determination of the sample is done by taking a sample of $15 \%$ of the population of 165 people, so that the sample in this study amounted to 30 respondents. Analysis of the data used
\end{abstract}


to answer the first, second and third purpose is descriptive analysis, to analyze the perceptions of farmers using a Likert Scale with the criteria for each response each category is 3 = strongly agree, 2 = agree, 1 = disagree, and to know about factors related to farmers' perceptions of AUTP analyzed using Rank Spearman correlation test. The results showed: 1) The implementation mechanism of the AUTP program in Paleteang District had gone well, but the socialization of the program was not comprehensive to all farmers, 2) The farmers 'perception of AUTP was divided into 3 aspects, farmers' perceptions of the AUTP implementation organization in the agreed category, perceptions the implementation of AUTP is in the agreed category, and farmers' perceptions of monitoring, evaluation, and AUTP reporting are in a disagreeable category, 3) There is a relation between factors that influence perceptions (age, education, land area, premiums, and knowledge) with farmer's perception of AUTP.

Keywords: perception, rice farming, insurance program

\section{Pendahuluan}

Sektor pertanian memegang peranan yang sangat penting bagi sebagian besar negara dengan kategori sedang berkembang. Hal ini dikarenakan sebagian besar negara berkembang di dunia masih mengandalkan sektor pertanian dalam pembangunan ekonominya, termasuk Indonesia.

Indonesia sebagai sebuah negara dengan bentuk kepulauan dan apalagi terletak di daerah khatulistiwa merupakan wilayah yang rentan terhadap perubahan iklim (Kamaluddin, et.al, 2012). Perubahan pola curah hujan, kenaikan muka air laut, dan suhu udara serta peningkatan iklim ekstrem berupa banjir dan kekeringan merupakan beberapa dampak serius perubahan iklim yang dihadapi Indonesia. Ini diperparah oleh risiko perkembangan pertambangan yang salah satu dampaknya adalah kerusakan ekosistem pertanian di lingkungannya (Meisanti, et.al, 2012).

Ketidakpastian yang terjadi terhadap sektor pertanian lama kelamaan membuat makin banyaknya gagal panen yang terjadi dan membuat banyak petani menjadi rugi sehingga sulit untuk hidup di garis kesejahteraan. Untuk itu penerapan asuransi terhadap sektor pertanian merupakan hal penting dan mendesak. Asuransi pertanian penting dilakukan karena ketidakpastian yang menyerang hampir seluruh petani di Indonesia sehingga potensi untuk terjadinya gagal panen menjadi sangat tinggi.

Kabupaten Pinrang merupakan salah satu Kabupaten di Sulawesi Selatan yang telah menerapkan asuransi pertanian mengingat banyaknya jumlah petani padi sawah di Kabupaten tersebut. Tercatat pada tahun 2017 terdapat empat kecamatan yang telah menerapkan asuransi dengan luas lahan yang berbeda-beda. Empat kecamatan tersebut adalah Kecamatan Tiroang dengan luas lahan sebesar 124,15 Ha, Kecamatan Mattirosompe sebesar 25 Ha, Kecamatan Duampanua sebesar 56,68, dan Kecamatan Paleteang sebesar 168,6 Ha.

Kecamatan Paleteang merupakan daerah dengan luas areal petani (yang menerapkan asuransi) paling luas di antara tiga kecamatan lainnya. Kecamatan Paleteang juga merupakan lokasi yang sering dilanda bencana berupa banjir dan gagal panen sehingga petani di daerah tersebut sering menjadikan asuransi pertanian sebagai sarana dan alternatif untuk mengatasi hal tersebut. 
Oleh karena itu, berdasarkan latar belakang dan permasalahan tersebut maka penelitian ini bertujuan untuk: 1. menganalisis mekanisme Asuransi Usaha Tani Padi (AUTP) di Kecamatan Paleteang, Kabupaten Pinrang; 2. menganalisis persepsi petani terhadap Asuransi Usaha Tani Padi (AUTP) di Kecamatan Paleteang, Kabupaten Pinrang; 3. menganalisis faktor-faktor yang berhubungan dengan persepsi petani Terhadap Asuransi Usaha Tani Padi (AUTP) di Kecamatan Paleteang, Kabupaten Pinrang.

\section{Metode Penelitian}

Penelitian ini dilaksanakan di Kecamatan Paleteang, Kabupaten Pinrang, Provinsi Sulawesi Selatan. Populasi dalam penelitian ini adalah seluruh petani yang mengikuti program Asuransi Usahatani Padi (AUTP) di Kecamatan Paleteang yaitu sebanyak 165 orang. Jumlah sampel yang diambil dalam penelitian ini yaitu dengan mengambil 15\% dari jumlah populasi yaitu 30 responden. Berdasarkan pendapat dari Arikunto (2002) bahwa apabila subjek kurang dari 100 lebih baik populasi diambil semua sebagai sampel, tetapi kalau lebih dari 100 maka dapat diambil antara $10-15 \%$ atau $20-25 \%$ atau lebih

Analisis data yang digunakan untuk mencapai tujuan penelitian 1) mengenai mekanisme pelaksanaan Asuransi Usahatani Padi (AUTP) dianalisis menggunakan metode deskriptif dengan melihat proses pelaksanaan asuransi mulai pengorganisasian sampai pada kegiatan monitoring dan evaluasi.

Untuk tujuan penelitian 2), menganalisis Persepsi petani mengenai asuransi pertanian di Kecamatan Paleteang, Kabupaten Pinrang, dianalisis secara deskriptif kuantitatif. Skor Penilaian AUTP diukur dengan menggunakan skala Likert. Kriteria untuk setiap tanggapan masing - masing kategori adalah $3=$ sangat setuju, $2=$ setuju, 1 = kurang setuju. Masing - masing kriteria memiliki rentang sebagai pembatas dengan kriteria lain.

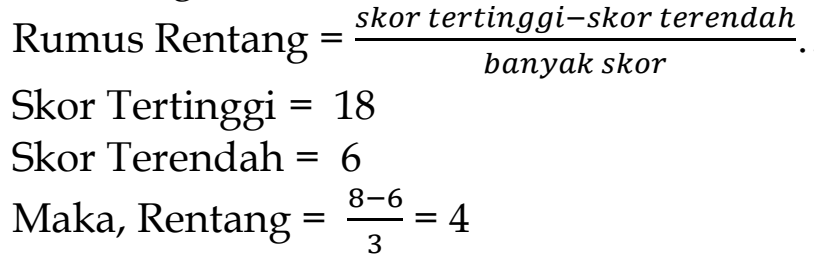

Tabel 1

Tingkatan persepsi Asuransi Usaha tani Padi (AUTP)

\begin{tabular}{ccc}
\hline No & Interval Kelas & Tingkat \\
\hline 1 & $6,00-10,00$ & Kurang Setuju \\
2 & $10,01-14,01$ & Setuju \\
3 & $14,02-18,02$ & Sangat Setuju \\
\hline
\end{tabular}

Untuk tujuan 3) tentang faktor-faktor yang berhubungan dengan persepsi petani terhadap Asuransi Usahatani Padi (AUTP) dianalisis dengan menggunakan uji korelasi Rank Spearman pada taraf kepercayaan $0.05 \%$ dengan rumus (Siegel, 1992) sebagai berikut:

$$
r_{s}=1-\frac{6 \sum_{i-1}^{N} d i^{2}}{N^{3}-N}
$$


Keterangan:

rs $=$ koefisien korelasi peringkat Rank Spearman

$\mathrm{di}=$ selisih antara peringkat bagi xi dan yi

$\mathrm{N}=$ banyaknya pasangan data

Karakteristik petani dan faktor ekstenal (variabel $x$ ) dalam hubungannya, dengan persepsi petani terhadap Asuransi Usaha Tani Padi (AUTP) ( variabel y) dianalisis dengan menggunakan uji korelasi rank Spearman. Pada uji korelasi rank Spearmen, signitifikasi hubungan dua variabel tampak dari nilai rs (koefisien korelasi) yang diperoleh dari hasil perhitungan. Bila $N$ (sampel) $\geq 10$, maka rs akan menyebar normal dengan standar deviasi $1 / \sqrt{ } \mathrm{N}-1$, sehingga hipotesis dibuktikan dengan menggunakan $Z=\sqrt{ }$ dimana hipotesis ditolak apabila $Z$ hasil perhitungan lebih besar daripada nilai $\mathrm{Z}$ pada tabel.

Adapun dalam menentukan tingkat kekuatan hubungan antar variabel, dapat berpedoman pada nilai koefisien korelasi yang merupakan hasil dari output SPSS, dengan ketentuan (Sahid, 2017) :

1. Nilai korelasi sebesar $0,00-0,25=$ hubungan lemah

2. Nilai korelasi sebesar $0,26-0,50=$ hubungan sedang

3. Nilai korelasi sebesar 0,51 - 0,75 = hubungan kuat

4. Nilai korelasi sebesar $0,76-0,99=$ hubungan sangat kuat

5. Nilai korelasi sebesar 1,00 = hubungan sempurna

\section{Hasil dan Pembahasan}

Prosedur yang dilakukan untuk menjadi peserta asuransi usaha tani padi harus terlebih dahulu tergabung atau terdaftar dalam kelompok tani dan tanaman padi yang dapat didaftarkan menjadi peserta asuransi harus tanaman padi maksimal berumur 30 hari, penilaian kelayakan menjadi peserta asuransi dilakukan oleh perusahaan asuransi pelaksana. Kemudian mengisi formulir pendaftaran yang akan didampingi oleh petugas pertanian.

Setelah terdaftar sebagai peserta asuransi usaha tani padi maka petani harus membayar premi sesuai dengan luas lahan yang didaftarkan. Total premi yang yang harus dibayar sebesar Rp. 180.000,-/ha/MT dengan bantuan dari pemerintah sebesar $80 \%$ atau sekitar Rp.144.000,-/ha/MT dari premi yang dibayar oleh petani. Jadi petani hanya membayar 20\% yakni sekitar Rp.36.000,-/ha/MT. Jika luas lahan yang diasuransikan kurang atau lebih dari 1 (satu) ha, maka besarnya premi (dan ganti rugi) dihitung secara proporsional.Kemudian Premi swadaya dibayarkan ke rekening asuransi pelaksana (penanggung) dan menyerahkan bukti pembayaran kepada asuransi pelaksana.

Jika terjadi risiko terhadap tanaman yang diasuransikan, kerusakan tanaman atau gagal panen dapat diklaim. Klaim Asuransi Usaha Tani Padi (AUTP) akan diproses jika memenuhi ketentuan yaitu menyampaikan secara tertulis pemberitahuan kejadian kerusakan kepada PPL/POPT-PHP dan Petugas Asuransi tentang indikasi terjadinya kerusakan (banjir, kekeringan dan OPT pada tanaman padi yang diasuransikan selambat-lambatnya 7 (tujuh) hari kalender setelah diketahui terjadinya kerusakan dan penyuluh pertanian dan POPT akan terlebih dahulu memeriksa kerusakan yang terjadi dilahan milik petani setelah itu akan ada 
petugas dari pihak asuransi yang memeriksa kembali kerusakan yang terjadi dilahan milik petani.

Faktor-faktor yang mempengaruhi persepsi dalam penelitian ini yaitu umur, pendidikan, luas lahan, premi, dan pengetahuan. Hasil data lapangan mengenai umur, pendidikan, luas lahan, premi, dapat diliat pada tabel :

\begin{tabular}{|c|c|c|c|}
\hline No. & $\begin{array}{l}\text { Faktor-faktor yang } \\
\text { mempengaruhi }\end{array}$ & Kategori & Hasil \\
\hline 1 & $\begin{array}{l}\text { Tingkat } \\
\text { pendidikan }\end{array}$ & $\begin{array}{l}\text { Tamat SD } \\
\text { Tamat SMP } \\
\text { Tamat SMA }\end{array}$ & $\begin{array}{l}\text { Tingkat pendidikan petani Kecamatan } \\
\text { Paleteang Tercatat bahwa sebagian besar } \\
\text { responden mengecap pendidikan } \\
\text { terakhir di bangku SMA dengan } \\
\text { persentase yaitu } 43 \%\end{array}$ \\
\hline 2 & Umur & $\begin{array}{l}\text { Umur } 34-42 \\
\text { Umur } 43-51 \\
\text { Umur 52-60 }\end{array}$ & $\begin{array}{l}\text { Sebagian besar masyarakat yang } \\
\text { mengikuti program AUTP di Kecamatan } \\
\text { Paleteang berusia antara } 43-51 \text { tahun } \\
\text { dengan presentase } 50 \% \text { dan tergolong } \\
\text { dalam umur yang produktif. }\end{array}$ \\
\hline 3 & Luas lahan & $\begin{array}{l}<1 \text { ha } \\
1 \text { ha }-1,5 \text { ha } \\
1,6 \text { ha }-2 \text { ha }\end{array}$ & $\begin{array}{l}\text { Sebagian besar petani yang mengikuti } \\
\text { program AUTP memiliki luas lahan }<1 \\
\text { Ha dengan persentase sebesar } 60 \%\end{array}$ \\
\hline 4 & Premi & $\begin{array}{l}<\text { Rp. } 36.000 \\
\text { Rp. } 36.000-\text { Rp. } 54.000 \\
\text { >RP. } 54.000\end{array}$ & $\begin{array}{l}\text { Sebagain responden yang membayar } \\
\text { premi }<36.000 \text { dan memiliki persentase } \\
\text { sebesar } 60 \% \text {. Jumlah premi yang dibayar } \\
\text { sangat dipengaruhi oleh jumlah lahan } \\
\text { yang ingin di asuransikan atau yang } \\
\text { didaftarkan. }\end{array}$ \\
\hline
\end{tabular}

Persepsi petani dalam penelitian ini akan diukur berdasarkan tiga indikator penting dalam asuransi sesuai dengan pedoman umum asuransi pertanian yaitu dalam hal organisasi pelaksanaan, pelaksanaan, monitoring, evaluasi dan pelaporan.

Tabel 2

Hasil Keseluruhan Rataan Nilai Skor Setiap Variabel Persepsi Petani Terhadap Asuransi Usaha Tani Padi (AUTP)

\begin{tabular}{clccc}
\hline No. & \multicolumn{1}{c}{$\begin{array}{c}\text { Asuransi Usaha Tani } \\
\text { Padi(AUTP) }\end{array}$} & $\begin{array}{c}\text { Skor Rata- } \\
\text { Rata }\end{array}$ & $\begin{array}{c}\text { Persentase } \\
\mathbf{( \% )}\end{array}$ & Kategori \\
\hline 1 & Organisasi Pelaksanaan & 12,56 & 35,87 & Setuju \\
2 & Pelaksanaan & 11,8 & 33,70 & Setuju \\
3 & $\begin{array}{l}\text { Monitoring, Evaluasi Dan } \\
\text { Pelaporan }\end{array}$ & 10,66 & 30,43 & Setuju \\
& $\begin{array}{l}\text { Total Skor Rata-rata } \\
\text { Seluruh Variabel }\end{array}$ & 35,02 & 100 & \\
\hline
\end{tabular}

Menjelaskan rataan nilai skor rata-rata setiap variabel persepsi petani terhadap Organisasi Pelaksanaan pada skor rata-rata 12,56 pada persentase 35,87\% kategori Setuju. Persepsi petani terhadap Pelaksanaan pada skor rata-rata 11,8 pada persentase 33,70\% kategori Setuju. Sedangkan Persepsi petani terhadap Monitoring, 
Evaluasi Dan Pelaporan pada skor rata-rata 10,66 pada persentase 30,43\% kategori Setuju.

Untuk menganalisis hubungan antara Faktor-Faktor Yang Mempengaruhi Persepsi Dengan Persepsi Petani Terhadap Asuransi Usahatani Padi (AUTP) di Kecamatan paleteang, Kabupaten Pinrang digunakan analisis Korelasi Spearman Rank. Variabel Asuransi Usaha Tani Padi yaitu Organisasi Pelaksanaan (Y1), Pelaksanaan (Y2) dan (Y3) Sedangkan untuk variable Faktor - faktor yang mempengaruhi Persepsi terbagi atas lima yaitu Umur (X1), Pendidikan (X2), Luas Lahan (X3), Premi (X4) dan Pegetahuan (X5). Hasil perhitungan analisis Spearman Rank dengan menggunakan SPSS berupa koefisien korelasi dapat dilihat pada tabel.

Tabel 3

Faktor-Faktor Yang Berhubungan dengan Persepsi Petani Terhadap Organisasi Pelaksanaan Menggunakan Analisis Rank Spearman, 2019

\begin{tabular}{clccccc}
\hline \multicolumn{2}{c}{ Spearman's rho } & $\begin{array}{c}\text { Umur } \\
(\mathbf{X} 1)\end{array}$ & $\begin{array}{c}\text { Pendidikan } \\
(\mathbf{X} 2)\end{array}$ & $\begin{array}{c}\text { Luas Lahan } \\
(\mathbf{X} 3)\end{array}$ & $\begin{array}{c}\text { Premi } \\
(\mathbf{X} 4)\end{array}$ & $\begin{array}{c}\text { Pengetahuan } \\
(\mathbf{X 5})\end{array}$ \\
\hline $\begin{array}{c}\text { Organisasi } \\
\text { Pelaksanaan } \\
(Y 1)\end{array}$ & $\begin{array}{l}\text { Koefisien } \\
\text { Korelasi N }\end{array}$ & 0,650 & $-0,581$ & 0,507 & 0,504 & 0,816 \\
\hline
\end{tabular}

Ket: * Berhubungan nyata pada $\alpha=0,05{ }^{* *}$ Berhubungan nyata pada $\alpha=0,01$

Tabel 4

Faktor-Faktor Yang Berhubungan dengan Persepsi Petani Terhadap Pelaksanaan Menggunakan Analisis Rank Spearman, 2019

\begin{tabular}{ccccccc}
\hline \multicolumn{2}{c}{ Spearman's rho } & $\begin{array}{c}\text { Umur } \\
(\mathbf{X} 1)\end{array}$ & $\begin{array}{c}\text { Pendidikan } \\
(\mathbf{X} 2)\end{array}$ & $\begin{array}{c}\text { Luas } \\
\text { Lahan } \\
(\mathbf{X} 3)\end{array}$ & $\begin{array}{c}\text { Premi } \\
(\mathbf{X} 4)\end{array}$ & $\begin{array}{c}\text { Pengetahuan } \\
(\mathbf{X 5})\end{array}$ \\
\hline & $\begin{array}{l}\text { Koefisien } \\
\text { Korelasi N }\end{array}$ & 0,416 & $-0,428$ & 0,608 & 0,605 & 0,873 \\
$\begin{array}{c}\text { Pelaksanaan } \\
(\mathrm{Y} 2)\end{array}$ & Signifikan & $0,022^{*}$ & $0,018^{*}$ & $0,000^{* *}$ & $0,000^{* *}$ & $0,000^{* *}$ \\
\hline
\end{tabular}

Ket: * Berhubungan nyata pada $\alpha=0,05 * *$ Berhubungan nyata pada $\mathrm{a}=0,01$

Tabel 5

Faktor-Faktor Yang Mempengaruhi Persepsi Dengan Monitoring, Evaluasi, dan Pelaporan Menggunakan Analisis Rank Spearman, 2019

\begin{tabular}{ccccccc}
\hline \multicolumn{2}{c}{ Spearman's rho } & $\begin{array}{c}\text { Umur } \\
(\mathbf{X 1})\end{array}$ & $\begin{array}{c}\text { Pendidikan } \\
(\mathbf{X})\end{array}$ & $\begin{array}{c}\text { Luas Lahan } \\
(\mathbf{X} 3)\end{array}$ & $\begin{array}{c}\text { Premi } \\
(\mathbf{X})\end{array}$ & $\begin{array}{c}\text { Pengetahuan } \\
(\mathbf{X} 5)\end{array}$ \\
\hline $\begin{array}{c}\text { Monitoring, } \\
\text { Evaluasi, } \\
\text { dan }\end{array}$ & Koefisien & 0,365 & $-0,479$ & 0,264 & 0,256 & 0,592 \\
$\begin{array}{c}\text { Pelaporan } \\
\text { (Y3) }\end{array}$ & Signifikan & $0,048^{*}$ & $0,007^{* *}$ & 0,159 & 0,172 & $0,001^{* *}$ \\
\hline
\end{tabular}

Ket: * Berhubungan nyata pada $\alpha=0,05 * *$ Berhubungan nyata pada $\alpha=0,01$. 


\section{Kesimpulan}

Berdasarkan uraian dari hasil pembahasan penelitian ini, maka dapat ditarik kesimpulan sebagai berikut :

1. Mekanisme asuransi pertanian di Kecamatan Paleteang, Kabupaten Pinrang berjalan dengan baik namun sosialisasi tentang program masih kurang menyeluruh kesemua petani dan petani menilai proses pengajuan klaim agak sulit dan pembayaran ganti rugi sering terlambat.

2. Persepsi petani terhadap asuransi usaha tani padi (AUTP) terbagi atas 3 yaitu : 1) Persepsi Petani Terhadap Organisasi Pelaksanaan Asuransi Usaha Tani Padi (AUTP) pada kategori setuju, 2) Persepsi Petani Terhadap Pelaksanaan Asuransi Usaha Tani Padi (AUTP) pada kategori setuju, 3) Persepsi Petani Terhadap Monitoring, Evaluasi, dan Pelaporan Asuransi Usaha Tani Padi (AUTP) pada kategori setuju

3. Terdapat hubungan antara faktor - faktor yang mempengaruhi persepsi (umur, pendidikan, luas lahan, premi, dan pengetahuan) dengan persepsi petani terhadap Asuransi Usaha Tani Padi (AUTP).

\section{Daftar Pustaka}

Arikunto, S. 2002. Prosedur Suatu Penelitian: Pendekatan Praktek. Edisi Revisi Kelima. Jakarta: Rineka Cipta.

Kamaluddin, A., A. Ala, MSS. Ali, D. Salman, 2012. "The Adaptation of Rice Paddy Farmers Towards Climate Change". American-Eurasian Journal of Agricultural and Environmental Science. 12 (7).

Meisanti, K. Jusoff, D. Salman, D. Rukmana, 2012. “The Impacts of Gold Mining on the Farmers Community". American Journal of Sustainable Agriculture, 6: 209-214. 